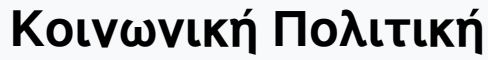

Tóp. 9 (2018)

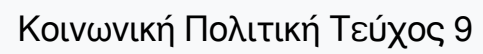

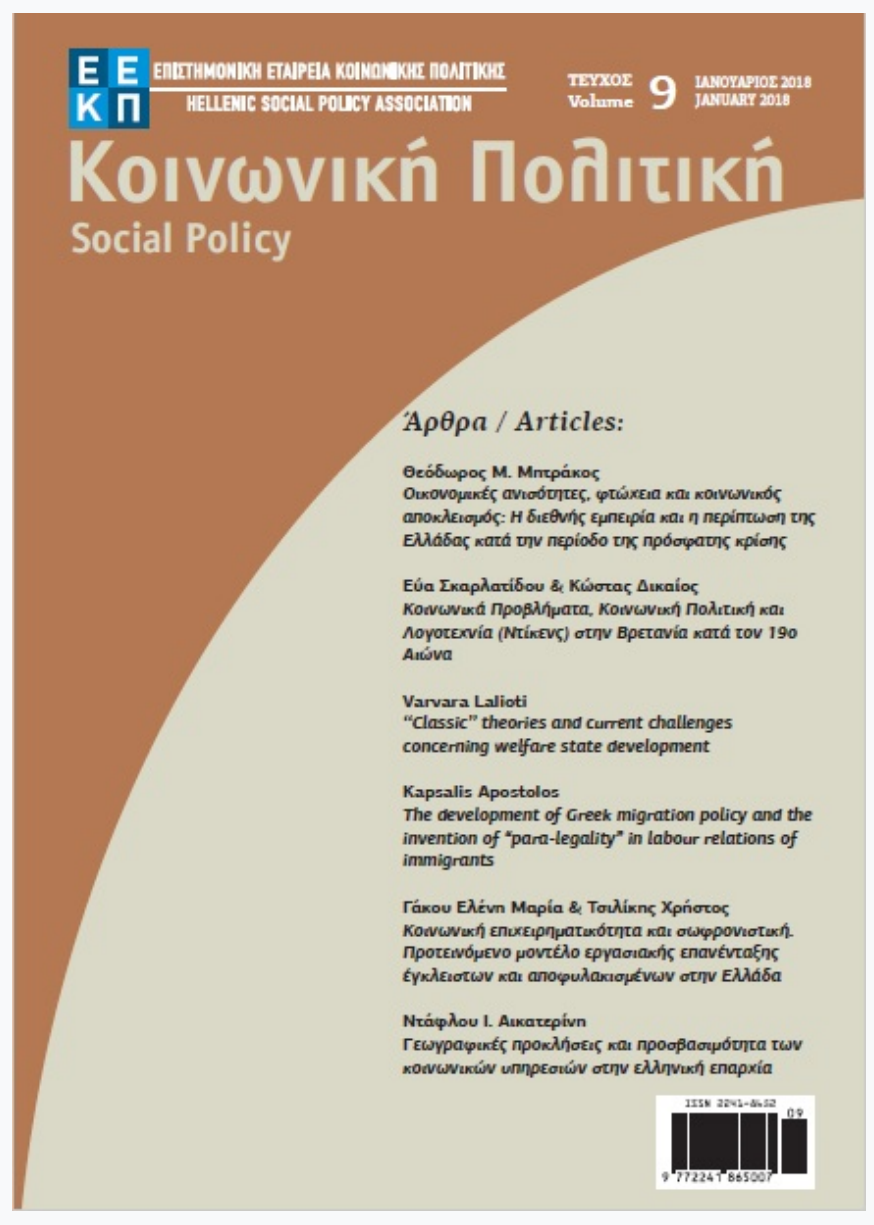

\section{"Classic" theories and current challenges concerning welfare state development}

Varvara Lalioti

doi: $10.12681 /$ sp.15985

Copyright $@ 2018$, Varvara Lalioti

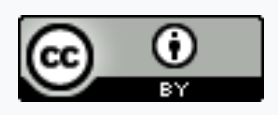

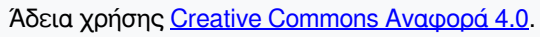

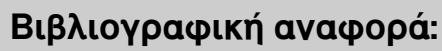

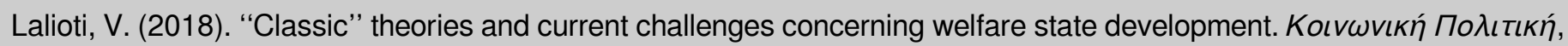
9, 47-66. https://doi.org/10.12681/sp.15985 


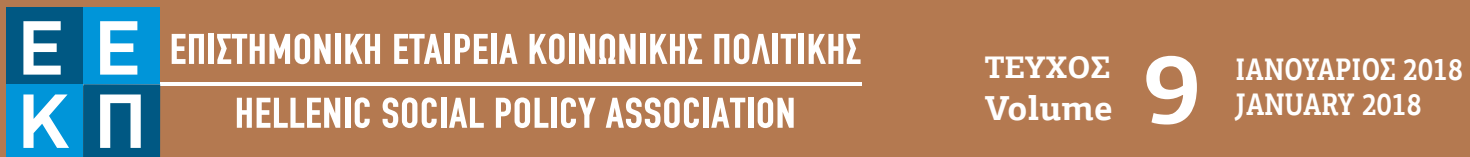

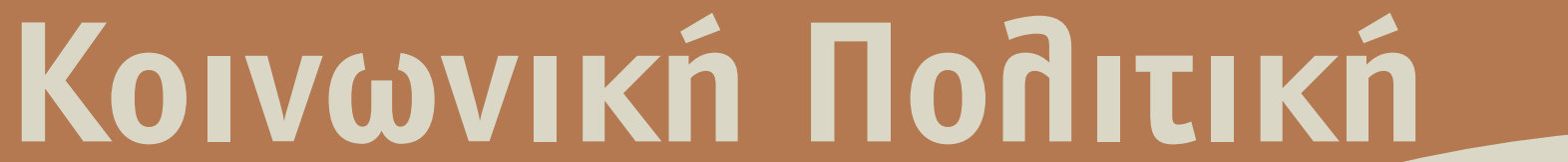

Social Policy

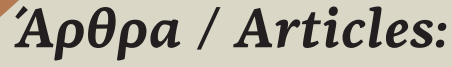

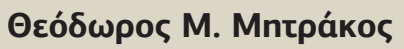

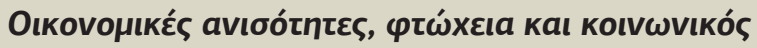

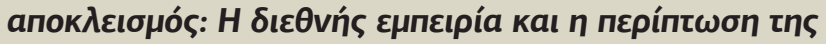

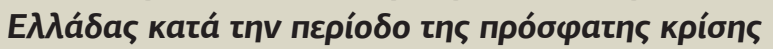

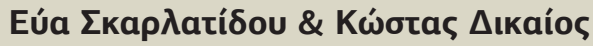

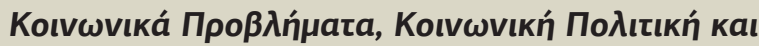

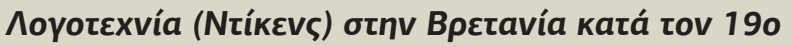
Aıćva

Varvara Lalioti

"Classic" theories and current challenges concerning welfare state development

Kapsalis Apostolos

The development of Greek migration policy and the invention of "para-legality" in labour relations of immigrants

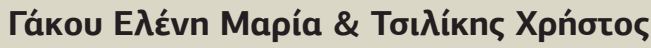

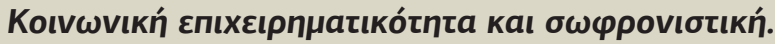

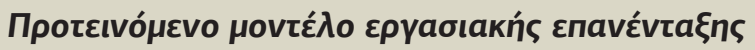

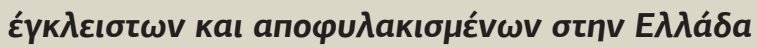

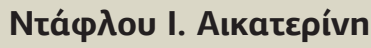

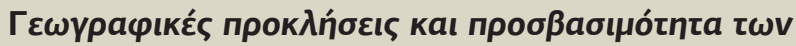

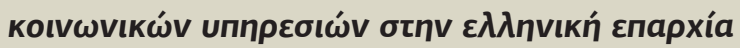

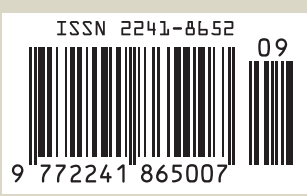




\title{
"Classic" theories and current challenges concerning welfare state development
}

\author{
Varvara Lalioti \\ Panteion University of Social and Political Sciences
}

\section{Abstract}

The aim of the present article is to provide the reader with a bird's-eye view of 'classic' theories concerning welfare state development, whilst also stressing the need for social policy to address current challenges faced by the welfare state, and thus 'transform' old theories in accordance with new research directions. The first part of the article provides a succinct critical examination of 'classic' theoretical approaches. These include industrialism, power resource theory, historical institutionalism, national values, business power, but also the broader trend of classifying welfare states that drew on features of the aforementioned approaches and introduced new variables such as gender. The second part of the article is devoted to powerful contemporary challenges for the welfare state, such as migration and growing ethnic diversity, neoliberal globalization and the recent crisis, as well as changing gender roles. It is argued that these challenges give rise to key questions for the field of social policy and test the limits of traditional assumptions for the welfare state. This part asks for a fruitful dialogue between the old and something newer that is needed to complement it. Such a dialogue is a prerequisite for rigorous and sophisticated social policy research. The article's concluding section summarizes the findings.

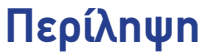

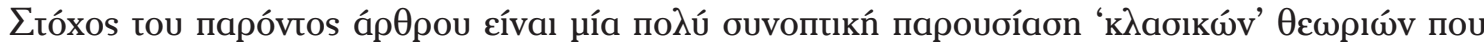

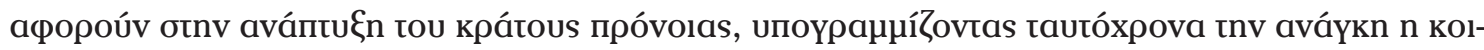

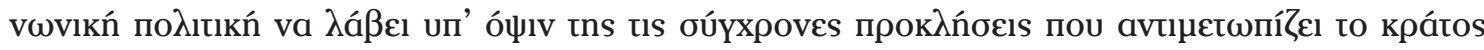

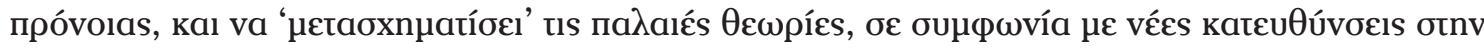

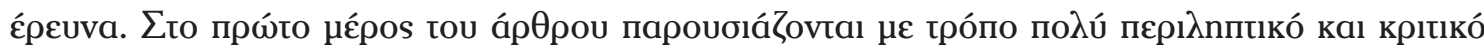

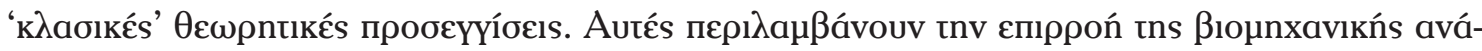

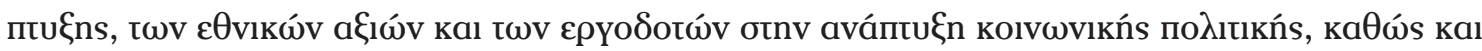




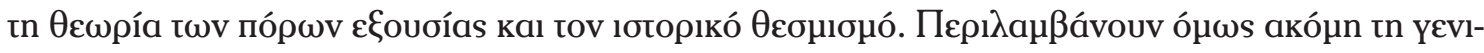

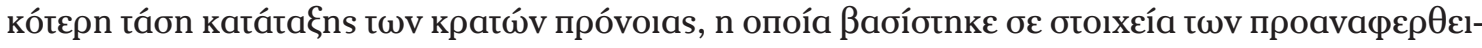

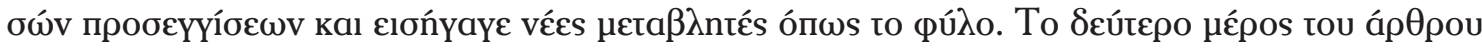

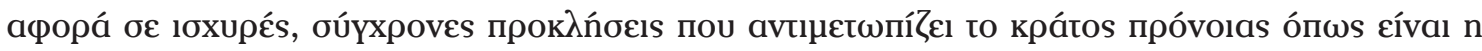

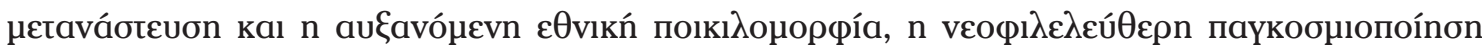

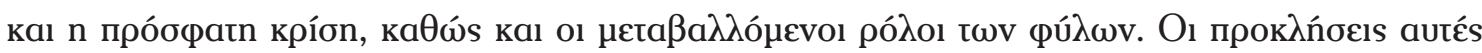

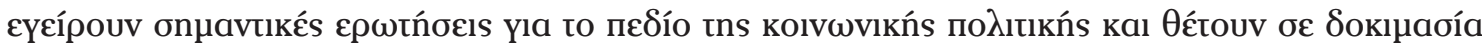

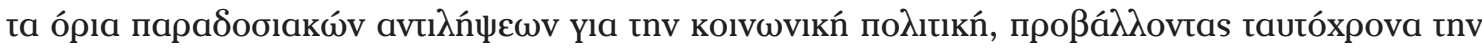

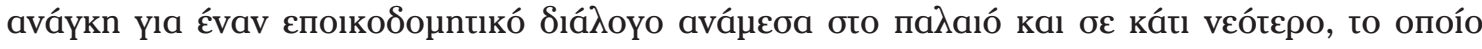

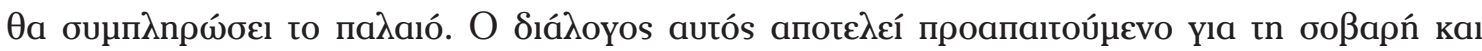

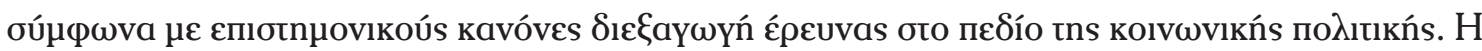

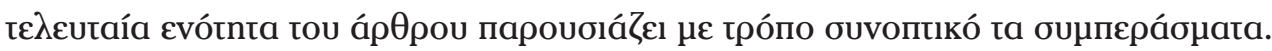

\section{Introduction}

Social policy issues and theories, regarded as 'classic', have dominated the field of social policy for decades. Are these issues and theories still central to contemporary social policy debates, debates that are also characterized by challenges that were often not present when the aforementioned issues and theories were first developed? At first glance, the answer appears to be affirmative: Examples may be found in concepts such as solidarity, social citizenship and welfare regimes, which were broadly discussed in the works of theorists such as Durkheim, Marshall and Esping-Andersen respectively and continue to lie at the heart of social policy research and analysis today.

The same statement can also be made for theories deemed to be 'classic'. Although the use of the adjective 'classic' may be criticized for being arbitrary and/or vague, it is useful for pointing to theories of recognized and established value that are also considered to be the most influential in the field of social policy. Such theoretical approaches underscore, for instance, the importance of institutions or business power for welfare state development. Despite the fact that scholars tend to build bridges between different theories so as to explain social policy phenomena, such approaches, acknowledged to be 'classic', remain at the centre of the field of social policy. Overall, the lessons learnt from the scholarship of the past are invaluable for shedding light on the present, and also the future of the field.

Nonetheless, at the same time, for a rigorous and sophisticated social policy analysis it is increasingly important to take into account the current challenges that the welfare state faces and which have often been overlooked by social policy scholars engaged in the examination and application of 'classic' social policy theories. These challenges include migration and the increasing salience of ethnic diversity, neoliberal globalization and the recent crisis, as well as changing gender norms. Given the importance of these challenges for present times, scholars must also examine the extent to which these challenges test the limits of traditional assumptions regarding welfare state development. 
Against this background, the aim of this article is to provide a bird's-eye view of the most 'classic' theories regarding the development of the welfare state, while underscoring the importance of the current challenges that the welfare state faces and the need to build a bridge between the old and something newer that will complement the former. The first section of the article provides a succinct and critical presentation of key theories for welfare state development, that is industrialism, power resource theory, historical institutionalism, national values, business power and the broader trend for classifying countries that have drawn on features of some of the aforementioned theories as well as introduced new variables, such as gender. The discussion does not follow a strict chronological order: the classification of welfare worlds is the last to be discussed, since it is based on features of the 'classic' theories.

The presentation of theoretical approaches/trends regarding welfare state development is apparently selective and not exhaustive. As a result, a number of approaches is not discussed, such as the one that underlines the role of the state as a social investment mechanism. Generally speaking, relatively new approaches concerning social policy development are not examined; nor is the contribution of these new approaches and the relationship between new and old theoretical trends.

The selected approaches are also characterized by different scope and level of theoretical coherence. Industrialism could be labeled as a macro-theory, that is associated with structural functionalism and focuses on the impact of a macro-process (industrialization) upon the general direction which states across the globe follow. Power resource theory, historical institutionalism and employer-centered theories are middle-range theories, which single out factors and observe how they contribute in the creation of historical welfare trajectories. Finally, some scholars may argue that the 'national values' approach is the one with the weakest theoretical coherence.

The second section of the article presents current main challenges for the welfare state, namely migration and growing ethnic diversity, neoliberal globalization and the recent crisis, as well as changing gender norms, followed by a concluding section that summarizes the findings. Similarly to the presentation of theoretical approaches/ trends regarding welfare state development the references made to current main challenges for the welfare state are selective. Challenges such as the impact of technological change and the transition to post-industrial society, the role of European integration, demographic ageing, changes in the labour market, the decline of the role of traditional social classes and trade unions and the emergence of "new social risks' in general are not discussed separately.

Moreover, the author wishes to stress that the article focuses more on the limits of traditional assumptions for the welfare state and new questions that arise than on exploring the potential of 'classic' theories to interpret current trends and developments in the welfare state in the light of the challenges faced by the welfare state. By contrast, the article aims at emphasizing certain suggestions on ways these 'classic' theories could be amended, so as to accommodate in their explanations the new challenges that the welfare state is currently facing.

Overall, the character of the article, that is a short and difficult (given the magnitude of the task performed and the limited space offered for this task) exercise on the relationship between 'classic' theoretical approaches to the welfare state and current challenges may arguably 
provide an excuse for the selectivity in both the aforementioned approaches and challenges. The author acknowledges the limitations of this exercise and humbly approaches the task performed.

\section{Key 'Classic' Theoretical Assumptions Regarding Welfare State}

\section{Development}

\section{Industrialism}

The first generation of theories regarding welfare state development focused on the impact of industrialization and related social and economic forces on the establishment and evolution of welfare programmes. This set of theories may be broadly labeled as 'functionalist' explanations of welfare state development. They assume that social policies are the immediate response to social and economic pressures, whilst regarding the political organization of social demands or governmental institutions as either neutral or fully determined by socio-economic change (Zutavern and Kohli, 2012, p. 173).

It has been argued that industrialization created new demands for public spending 'as systems of social support based on kinship and the patrimonial traditions of agrarian societies are eroded' (Myles and Quadagno, 2002, p. 36). In conjunction with a growing dependence on wage labour and the emergence of new vulnerabilities, this context encouraged an increased role for the state. Wilensky (1975) is among the best known if not the most well-known proponent of the 'industrialist' school, who argues that economic growth mediated by demographic change is the key explanatory variable for welfare state development.

Although the idea that industrialism and its correlates, that is economic growth and population ageing, are crucial in explaining the overall trend of welfare state expansion is rarely questioned, it is widely contested whether this theory can explain variations in welfare state development. In particular, it is rather unrealistic to argue, as this school of thought does, that politics does not matter and that only impersonal, economic forces have the power to shape social policy, or that worker organizations and employers are nothing more than passive actors.

Indeed, Wilensky (1975) himself acknowledged that other factors, such as the degree of government centralization and the shape of the stratification order account for crosscountry variation in welfare provisions. Furthermore, more recently, in his seminal book Rich Democracies: Political Economy, Public Policy, and Performance (2002) Wilensky demonstrated how differences in bargaining arrangements among government, political parties, the mass media, industry, labour, professions, agriculture, churches, and voluntary associations lead to contrasting policy profiles and patterns of taxing and spending, which in turn explain a large number of outcomes: economic performance, political legitimacy, equality, job security, safety and risk, real health, the reduction of poverty and environmental threats, and the effectiveness and fairness of regulatory regimes. 


\section{Power Resource Theory}

By the end of the 1970s the hegemony of 'functionalist' arguments for welfare state development, as exemplified by 'industrialism', gave their place to the acknowledgement that 'politics matter'. This is a motto that is found at the heart of both 'political' and 'institutional' explanations of welfare state development, according to which organizational capacities and institutionalized procedures for decision-making are regarded as crucial for the design and evolution of social policies (Zutavern and Kohli, 2012, p. 174).

Power resource theory is arguably the most influential among the theories linked with the 'politics matters' motto. Most closely associated with the work of Korpi (1980) and later EspingAndersen (1985a, 1985b, 1990), it looked at the influence of interest groups, notably organized labour. The main argument promoted by the power resource theory was that workers could use their power resources in a way that would reduce inequality and increase redistribution. As a result, major differences in the development of welfare states can arguably be explained by the relative success of left parties, aligned with strong trade unions.

Esping-Andersen argued that the effectiveness of working-class power resources depends on a series of additional factors, such as the conditions open to working-class parties to forge alliances with other social classes (Esping-Andersen, 1985b, p. 223). Overall, the size and the structure of the welfare state is explained as a function of the historical strength of the political left, mediated by alliances with agrarian interests and the middle classes (Iversen, 2012, p. 185). The importance of working class mobilization for explaining differences in welfare state development is highlighted in cross-national research (e.g., Huber, Ragin, and Stephens, 1993; Hicks, 1999).

The criticisms of power resource theory include the fact that stable cross-national differences in government partisanship are not adequately explained. Nor does the theory distinguish between the preferences of parties and the preferences of voters (Iversen, 2012, p. 186).

\section{Historical Institutionalism}

In the 1980s, a number of scholars, the best known being Skocpol (Skocpol, 1985, 1992; Weir, Orloff, and Skocpol, 1988; Amenta, 1998), began to emphasize the importance of the organization and structure of state institutions for welfare state development. This development is considered to have paved the way for the 'historical institutionalist' approach to welfare state development. The term 'historical institutionalism' was coined by the Steinmo, Thelen, Longstreth volume Structuring Politics: Historical Institutionalism in Comparative Analysis published in 1992.

Historical institutionalism developed in reaction to approaches such as industrialism and power resource theory, which focused on economic factors and social classes respectively. It had a historical orientation and highlighted the ways institutions structure and shape social policy outcomes (Steinmo, 2008).

At the centre of historical institutionalism lies the idea that the state needs to be treated as 
an autonomous factor and that it does not simply reflect the interests of business and labour organizations. States are regarded as actors and structures which influence the organization, goals, and resources of social actors. By contrast, historical institutionalism de-emphasized the role of organized interests (Heclo, 1974).

Historical institutionalism embraced the idea that political institutions, despite their complex and multifaceted role, shape welfare state development. In a similar vein, variation in electoral rules and party systems can have an impact on welfare state politics. The rules of electoral competition and the institutional features of government are important in determining social policy outcomes. It has also been argued that existing social policies shape the politics of reform through a 'policy feedback' (Pierson, 1993). However, policy feedback may not necessarily lead to path dependence (Weaver, 2010).

Criticism of historical institutionalism includes the claim that it is incapable of coping with change. It is argued that the central analytical notion of 'path dependence' may translate into some neglect of the forces for change (Peters, Pierre and King, 2005). Overall, institutions created in the past are thought to constrain future developments.

Moreover, broadly speaking, the impact of institutions seems to depend on the context (Béland and Mahon, 2016, pp. 25-26). Lastly, it has also been argued that 'historical institutionalism' refers to a rather loose collection of writings by authors that tend to mix elements from different explanations of the welfare state (Immergut, 2008, pp. 241-242).

\section{National Values}

The 'national values' approach draws on the assumption that variation in cultural values is the main explanation for differences in the development of welfare states. Shared cultural beliefs have an impact on voters and policy makers, and guide the selection of particular policy options, as opposed to other options. Levine (1988) and Lipset (1990) are among the main representatives of this approach.

Different constellations of values might lead to different policy logics in different countries or types of regimes. For example, the greater prevalence of individualistic values in the United States compared to Canada has been argued to have resulted in the development of a weaker welfare state in the former, as opposed to the latter country.

Similar assumptions are at the centre of research that focuses on patterns of welfare attitudes, as exemplified by whether citizens are supportive of or against an encompassing welfare state (Svallfors, 2012). They are also at the heart of studies that seek to trace the impact of religious doctrines on principles of social policies. Religion in particular is acknowledged as being a major cultural force that may shape the values, norms, beliefs and attitudes of citizens in favour of or against specific social policies and the welfare state in general. For example, it has been argued that corporatist-conservative welfare states were more likely to emerge in predominantly Catholic societies, liberal welfare states in areas influenced by Reformed Protestantism, and social democratic welfare states in the Lutheran countries of Scandinavia (Kersbergen and Manow, 2012, pp. 267-268). 
The 'national values' approach has been criticized for promoting a high level of generality, which cannot provide a solid explanation for, for instance, why there is internal variation in welfare state development across policy areas within the same country (Skocpol, 1992; Béland, 2010). For this reason, other scholars such as Skocpol (1992) and Myles (1998) underscore the importance of a more detailed institutional and political analysis that considers the forces driving policy design in each policy area.

\section{Business Power}

A variation of the power resource theory that has inspired many scholars, including EspingAndersen, is one that focused not on the importance of working class power, but on the impact of business on welfare state development. Although such studies found a relative popularity in the United States in the works of scholars such as Gordon (1991), Quadagno (1984) and Domhoff (1996), who stressed the effect of industrialists on the formulation of social policy legislation, the 'business power' theory would experience its most glorious days after the mid1990s.

Milestones included the debate between Swenson (1997) and Hacker and Pierson (2002), on the one hand, and the 'varieties of capitalism' $(\mathrm{VoC})$ school on the other. While Swenson adopts a more straightforward idea about how business interests shape social policy decisions, Hacker and Pierson combine business power with historical institutionalism and argue that political institutions filter the political impact of business interests.

The VoC approach, as exemplified by the works of Hall and Soskice (2001) and Mares (2003), argues that there is a correspondence between types of political economies and types of welfares states. In that sense, it builds a bridge between functionalist and institutionalist assumptions. This approach draws on the assumption that economic institutions are designed to help firms and other economic agents to make the best use of their productive assets, and also that there are 'institutional complementarities', where the effectiveness of one institution depends on the design of the other. More recently, others (see Fleckenstein and Seeleib-Kaiser, 2011) have combined the power resource theory with the VoC school and argue that the types of welfare policies adopted in different countries reflect the distinctive character of the postindustrial skill profiles in these countries, which have in turn shaped business attitudes towards social policy programmes.

Criticism of the 'business power' theory included the argument that it neglected the role of other powerful actors, such as state bureaucrats, and offered a simplistic analysis of the policy process (Skocpol, 1992). Korpi (2006) also claimed that business is rarely a protagonist, but it can often play the role of the consenter. Furthermore, relevant to the weaknesses of the 'business power' theory is the fact that the relationship between economic and political institutions remains an under-explored topic. As Iversen mentions, it is striking that the division into liberal and coordinated market economies is almost perfectly collinear with the division into PR and majoritarian electoral systems' (Iversen, 2012, p. 193). 


\section{Classifying Welfare States}

The importance of politics and political institutions for welfare state development, as opposed to industrialism, was also to be stressed in Esping-Andersen's seminal work Three Worlds of Welfare Capitalism (1990), which paved the way for an increasing move towards the classification of welfare states. Following the footsteps of Wilensky and Lebeaux (1958) and Titmuss (1974), who differentiated between different patterns of welfare performance, Esping-Andersen placed the triad of 'state-market-family' at the centre of his analysis and identified three distinct 'welfare regimes': the liberal, the corporatist and the social democratic.

Liberal welfare states are reluctant to replace market relations with social rights, while means-testing is extensive and social insurance modest. Corporatist welfare regimes are concerned with maintaining the status quo, while favouring subsidiarity and the primary role of the family in welfare. Income transfers to cover the needs of the male breadwinner are emphasized, as opposed to social services. At the heart of the social democratic welfare regime lie extensive, universal social rights, in contrast to the marginal role of private welfare provision. The social democratic welfare regime is service-oriented and places considerable emphasis on redistribution.

Esping-Andersen's main contributions include concepts such as 'welfare regime', 'decommodification' and 'stratification', as well as the thesis that the type of welfare regime affects a country's post-industrial trajectory. His theory has common features with both historical institutionalism and the power resources thesis. As far as historical institutionalist features are concerned, Esping-Andersen assumes that there are path dependent responses to contemporary challenges, and that while politics initially shape social policy regimes, the latter have an impact on subsequent political alignments. In terms of power resources theory, Esping-Andersen uses a version of this theory, highlighting, among other things, that social democratic welfare regimes are most likely to emerge where there is presence of strong unions and parties of the left and a working class that can forge effective coalitions with others (Béland and Mahon, 2016, pp. 28-31).

Esping-Andersen's typology was subject to significant criticism. Some argued that there are more than three worlds of welfare regimes, such as the southern European regime (Ferrera, 1996) and a 'radical' welfare regime made up of Anglophone countries (Castles and Mitchell, 1993). The main criticism came, however, from feminist scholars, who argued that EspingAndersen emphasized class at the expense of gender. Feminists such as O' Connor (1993) and Orloff (1993) criticized Esping-Andersen for overlooking the way in which women's participation in paid work could lessen their dependence on men. The result was the construction of alternative, gender-based systems for classifying welfare regimes.

Gendered regimes followed different paths of development, which reflect different processes of the exclusion and integration of women in the productive economy, different institutional arrangements in the labour market and a different evolution of family and social systems, including relations between the genders (Rubery, 2014). Lewis (1992) was the first to stress that the male breadwinner model is key to the architecture of all welfare regimes. In 1996, Sainsbury 
spoke of two ideal types of social policy models, one centred on the male breadwinner and another centred on the individual. According to Sainsbury, the strength of the male breadwinner model depends on factors such as the type of family ideology and the degree to which women's care work is paid or unpaid.

Feminists such as Orloff (1993) engaged directly with the idea of three worlds of welfare regimes, also pointing out that stratification occurs along both gender and class lines. Others pointed to the existence of intra-regime differences related to gendered assumptions, as exemplified in the work of O' Connor, Orloff and Shaver (1999) who showed that the Australian, British, Canadian and US welfare regimes, regarded as liberal, in fact exhibit important differences in their gender models.

Moreover, the idea of gender-based welfare states is closely related to the discussion of care. Sometimes care is discussed as a question of women's differences from men and as a barrier to employment, and other times as a socially necessary activity, which is not always recognized as such. This debate triggered studies on care regimes, as exemplified by the works of Bettio and Plantenga (2004) and others. Although non-familial care services, both marketized and public, have developed, women still do a disproportionate amount of unpaid care. The social organization of care affects the quality of women's employment and has inspired work on care regimes and national employment models (see, for example, Simonazzi, 2009).

In response to the criticisms expressed by feminists, Esping-Andersen proposed the adoption of the concept of 'defamilialization', focusing on policies that make it possible for individuals to exist 'independently of familial or conjugal reciprocities' (Esping-Andersen, 1999). Yet, the typology established by Esping-Andersen remains robust and, despite the challenges discussed in the next section, his thesis remains central to debates about how to classify and compare welfare states.

\section{Current Challenges to the Welfare State}

\section{Migration and Growing Ethnic Diversity}

When public welfare systems emerged, European nation states were often imagined as being ethnically and culturally homogeneous. Furthermore, the emergence of these systems was a way not just to reduce class conflict, but also to consolidate nation states. In this context, histories of the incorporation (or not) of immigrants and minorities, as well as reliance on foreign labour, were frequently ignored by social policy scholars. Minimal room was left to study the significance of migration and ethnic diversity for welfare systems. Overall, mainstream theoretical approaches tended to ignore the role of migration and ethnic diversity for the understanding of the welfare state, as exemplified by the fact that most social policy scholars failed to pay adequate attention to the role of migration in providing a workforce in order to staff care services in ageing societies (Esping-Andersen, 2003).

Exceptions to such studies, which examine the impact of migration and ethnic diversity on 
welfare state development, can largely be found in works that attempt to explain the rudimentary character of the welfare state in the United States, as opposed to the more generous nature of European welfare states, as the result of migration and multiculturalism versus homogeneity (see, for example, Alesina and Glaeser, 2004). In studies that rarely linked an understanding of racism and discrimination with the analysis of citizenship and social exclusion, let alone multiculturalism, citizenship and the welfare state, reference was made mainly to two categories of people: immigrants, defined as foreign-born persons who migrated mainly to developed countries, and people belonging to ethnic minorities, who were categorized as different from the majority population through appearance, religious practices, language use and customs (Castles and Schierup, 2012, pp. 278-279).

By the beginning of the 21 st century, migration and the issue of ethnic diversity had become increasingly important as social phenomena. During the last years in particular, the refugee crisis and the waves of mass migration, especially from countries of the Middle East and Northern Africa, have become a major issue, mainly in Europe. This has been accompanied by Islamophobia, populist anti-immigration movements and a growing preoccupation with terrorism. While, overall, migrants have their roots in increasingly different societies (Castles and Miller, 2009), they are also highly concentrated in specific neighborhoods often lacking good housing stock and public amenities and over-represented amongst the unemployed and amongst people below the poverty line (Schierup, Hansen and Castles, 2006).

This situation results in the gradual transformation of welfare states, through mechanisms such as the emergence of a climate of public opinion that is friendly/hostile to welfare transfers to immigrants and minorities and the growth of parties that are friendly/hostile to the aforementioned categories of people (Banting and Kymlicka, 2006). It has also provided fertile ground for a discussion on the impact of migration and ethnic diversity on social policies. Indeed, there is evidence that an EU migration regime is emerging, which is in many aspects modelled on US anti-discrimination policies (Castles and Schierup, 2012, p. 290).

Against this background, a number of key questions arise, relating to a series of interrelated issues: whether immigrants and minorities are excluded from welfare benefits or whether they are partially or fully incorporated into the welfare state; the features that helped shape the way immigrants and minorities have been incorporated into societies; whether the state takes care to register the special needs of immigrants and minorities; the existence of special services provided to these categories of people; whether growth in migration and ethnic diversity undermines popular support for the welfare state and whether it promotes welfare state reforms, in the sense of helping to legitimate the restructuring of welfare states; whether the increase in migration flows and ethnic diversity works in favour of more universal or more residual welfare approaches; and the way that political ideology interacts with the rise in migration and ethnic diversity so as to transform the welfare state.

In the light of growing migration and ethnic diversity, the limits of all the traditional assumptions for welfare state development must also be tested. The issues that should be examined include the following: the impact of the increase in ethnic diversity on a country's growth and economic development and the way this shapes welfare policies; the relationship between political parties and migrants; the strength of the political right or left as a reflection of ethnic 
diversity and its implications for the provision of welfare benefits; the effect of the aforementioned increase on the attitude of state institutions towards welfare policies; the impact of migration flows on the dominant cultural values in a country and its implications for the welfare state; the way that the increase in the number of immigrants affects the attitude of employers towards the welfare state; the use of migration as a possible vehicle for the recommodification of labour; the relationship between migration regimes and welfare regimes and the role that the type of welfare regime plays in determining whether immigrants will be granted adequate support or not.

Social policy scholars must attempt to take into account all the issues mentioned above, and prioritize the study of the interaction between welfare regimes and incorporation regimes. The latter 'consist of rules and norms that govern immigrants' possibilities to become a citizen, to acquire permanent residence, and to participate in economic, cultural and political life' (Sainsbury, 2012, p. 6). Moreover, scholars should pay more attention to the role played not only by economic forces, institutions, political and social actors, and cultural values, but also by ideas. One needs to ask what is the role that ideas play in exacerbating or mitigating the impact of migration and ethnic diversity on social policy development. In this respect, the relationship between nationalism (and its various forms) and social policy, as exemplified by 'welfare chauvinism', meaning the exclusion of 'outsiders' from national health and social benefits, is particularly understudied.

Overall, the complex relationship between increasing migration flows, the growing diversity of populations and welfare state development is an important one to analyse (Castles and Schierup, 2012, p. 280), especially since social policy is increasingly being perceived as global policy. The issues listed above are important enough to be studied not only in Europe and the developed countries of the northern hemisphere, but also in the Global South; mainly in multiethnic countries that struggle with massive diversity (Béland and Mahon, 2016: 83, 85-86).

\section{Neoliberal Globalization and the Recent Crisis}

The idea that globalization, that is international market integration, may pose a threat to the welfare state is not new. For example, it was long believed that neoliberal globalization may lead to welfare state retrenchment or dissolution (Cerny, 1997; Mishra, 1999) and that states with more developed welfare regimes may be better placed to cushion the impact of increased international competition (Garrett, 1998; Swank, 2002). Seminal is also the relevant work of Andrew Glyn under the title Capitalism Unleashed, Finance, Globalization and Welfare (2006).

Nonetheless, the 2008 financial crisis rekindled the debate between those contending that welfare state recalibration remained on the agenda and those arguing that the resurgence of neoliberal globalization, linked to the crisis, enforced austerity at the national level. Despite voices claiming that a final assessment can only be made in the long run (Pierson, 2011), it appears that those claiming that the crisis has brought back the spectre of globalization-induced austerity have won. Following the US housing market bubble the crisis quickly spread, leading to bank failures in the UK, Ireland and Iceland. The Great Recession spread throughout the 
Eurozone, hitting with particular severity the Irish, Portuguese, Spanish, Italian and Greek economies (Farnsworth and Irving, 2015).

The efforts of neoliberal fiscal consolidation were associated with the extensive restructuring of social programmes and severe cuts in welfare expenditures, especially in southern European countries (Ayhan and McBribe, 2015). In the latter, the result was the marked retrenchment of social rights, or, at best a process of 'subtractive recalibration' that largely reduced the protection of 'insiders' (Guillén and Pavolini, 2015, p. 150).

Overall, the 'neoliberal experiment', although it failed to deal with the financial crises of 2008-2009, was extensively utilized so as to allow markets to operate more freely and to restrain state interventions (Lehndorff, 2012). The growth of public debt as a reaction to the financial crisis provided the opportunity for the current crisis to be seen not as a consequence of the behaviour of banks and market deregulation, but as a consequence of the waste promoted by the contemporary welfare state (Karamessini and Rubery, 2014). Supranational institutions, mainly the European Commission, the Central European Bank and the IMF, played a key role in the restructuring and cuts in welfare expenditures.

Against this context, a number of key questions arise that deal with a series of interrelated issues. These include: the extent to which welfare policies are shaped by international forces, as opposed to national circumstances and actors; the impact of neoliberal orthodoxy on welfare states and its relationship with market-oriented welfare reforms; the mechanisms through which neoliberal globalization may shape national social policy choices; the pressure to remodel welfare regimes along neoliberal lines; whether there are countries that chose austerity without having it imposed by international constraints or countries where the crisis accelerated the process of social policy expansion; whether there are alternatives to austerity; what are the chances that the same institutions that mediated and shaped welfare states in the age of expansion are now shaping domestic responses to neoliberal globalization; and what are the chances that neoliberal globalization will lead to a convergence towards a liberal model of modest benefits, extensive means-testing and significant private insurance and services.

Although arguably historical institutionalists cannot be held responsible for not reshaping their methodological tools to accommodate developments such as those described in this section (see, for example, Streeck, 2014 and Thelen, 2014), in general the resurgence of neoliberal globalization makes it necessary to view most 'classic' theories regarding welfare state development in the light of the serious implications of globalization for welfare states. In the context shaped by the dramatic consequences of the crisis, the thesis that socioeconomic forces determine the design and evolution of welfare policies seems to be confirmed much more than any other theory; especially compared to the power resource thesis that pays attention to the key role political and social actors, such as leftist political parties and unions, play for welfare state expansion. Indeed, the new politics of the welfare state in the years of the crisis have largely been concerned with social policy formation in an age of austerity, where slow growth provided a favourable environment for cuts in welfare expenditures.

On the other hand, Armingeon, Guthmann and Weisstanner (2016) suggest that large budget consolidations tend to be associated with welfare state retrenchment and that during budget consolidations implemented by broad left-wing coalition governments, welfare state 
retrenchment is greatest. However, Hübscher (2016) shows that governments on both the left and right are equally likely to implement cuts. A crucial question to ask is: How do neoliberal globalization and the recent crisis affect the social welfare preferences of individuals and the interest associations and political parties that represent them?

Social policy research must pay attention to the weakening of the impact of national actors on policy-making and the increasing involvement of global/transnational actors in the design and development of welfare policies. Unsurprisingly, in a context that is largely defined by the policy decisions of these latter actors, global social policy is increasingly established as a solid field of social policy research. In a similar vein, a system of transnational social governance plays an increasingly central role in social policy debates (Béland and Mahon, 2016, pp. 90-99).

The roles played by social movements and non-governmental organizations should also be highlighted. Moreover, social policy scholars should shed light on whether neoliberal globalization and the recent crisis have changed the features of welfare regimes, encouraging the move and convergence towards a more residual social model, as exemplified by the strengthening of means-testing at the expense of more universal arrangements.

Social policy scholars should also ask which of the changes incorporated can be counted as a regime shift. Are Pierson's arguments that radical transformation of existing welfare institutions is unlikely still valid? Pierson $(1994,1996)$ argued that the political unpopularity of cutbacks to programmes that benefit large sectors of the population imposes high political costs for governments. Hence, governments tend to proceed to negotiated settlements with opposition parties, organized labour and business associations, spreading the blame for reform. In this context, dramatic change is arguably unlikely. Nonetheless, the dramatic implications of the current crisis largely eroded certainties and conventions of the past, and have made consensus-building processes more difficult.

\section{Changing Gender Norms}

Changes in gender norms are a direct consequence of the severe implications of the recent crisis. At a first glance, it seems that the crisis has resulted into an overall improvement in gender equality, but this a phenomenon that is largely due to the worsening of the labour position and prospects of men rather than progress in the labour position and prospects of women. Indeed, the crisis brought a downward levelling of the most important gender gaps in terms of employment, economic activities and wages, at the expense of men and in favour of women, with the exception of the gap in unpaid housework and care. The decrease in differences between the genders with regard to employment and economic and wage patterns was also accompanied by the persistence or even increase of differences within genders, based on class and education (Bettio and Veraschchagina, 2014).

Although the crisis has put an end to the long-term increasing trend of female employment, interestingly, at the same time, women and not men were those who increased their participation in the labour market during the years of the crisis, often as a means to compensate for the loss of 
the employment positions of the men in the family. The crisis reinforced the phenomenon of the 'added employee', as opposed to the phenomenon of the 'discouraged employee' (Karamessini and Rubery, 2014, p. 324).

The crisis has also resulted in changes to the family model. While in 2007, just before the crisis struck, dual-earner couples accounted for $74.1 \%$ of all couples with at least one workingage partner in the 24 European countries included in the EU-SILC survey, at the end of 2009 there was a $5.1 \%$ decrease in the percentage of dual-earner couples. Moreover, there was a $4.7 \%$ increase in the number of couples headed by a female breadwinner (Bettio and Veraschchagina, 2014, pp. 69-70). This means that while men were losing their jobs, women remained in or (re)entered the labour market, while the crisis has stopped the evolution towards a universal family model with two adult employees. Nor does there seem to be a return, however, to more traditional family structures. These would require that male employment be guaranteed with wages that would be adequate for men to provide for the entire family (family wages).

Furthermore, the reinforcement of neoliberal policies and the ensuing cuts in social expenditures threaten to reverse the tendency of the family, and women in particular, to become more 'independent' from care. For example, in Greece, one of the countries most harshly hit by the crisis, if not the most harshly hit, since 2010 there has been a $60 \%$ decrease in state subsidies for local administration. Given that local administration is responsible for the provision of childcare, this has resulted in a decrease in the overall quality of the services offered. At the same time, the number of applications to public nurseries and kindergartens increased dramatically (Karamessini, 2015, p. 264). The increasing 'defamilialization of care', which means that care is an increasingly low-ranked national state priority, results in even greater pressure on the unpaid employment of female family members, who also continue to suffer disproportionately from lower wages than men.

Strikingly, during the crisis years, the strength of administrative mechanisms relating to gender equality was significantly reduced or even abolished in a number of countries. The ultimate message emanating from such changes is that gender equality and related policies are, in times of crisis, at best a distraction from more pressing problems, such as poverty and unemployment (Karamessini and Rubery, 2014, p. 334).

Against this background, a number of important questions arise for researchers to further explore. These are associated with a series of interrelated issues and include: whether the implications of the crisis mark a crucial turn for the overall evolution of gendered relationships; which are the intended and unintended consequences of the crisis on gender norms; whether the crisis can be translated into an increasing distance from the model of the male breadwinner; how do other variables such as education and class interact with gender so as to define the life and employment paths followed by men and women during the crisis; whether the crisis gives birth to a new relationship between gender and welfare regimes; which kind of welfare regimes most encouraged the decline in the dual-earner family model and the rise in female breadwinner couples; and finally, the role of organizations representing women in the promotion of solidarity.

In this context, the limits of some of the assumptions made in the classic social policy theories are tested, especially the concept of 'defamilialization', which was designed to identify social policies 'that lessen individuals' reliance on the family; that maximize individuals' command 
of economic resources independently of familial or conjugal reciprocities' (Esping-Andersen, 1999 , p. 45). For feminists, defamilialization meant capturing the extent to which policies contribute to altering the balance of power between men and women, and thus the terms and conditions under which people engage in familial or care arrangements (Lister, 1994). Central to defamilialization as Esping-Andersen defined it, is a process of 'individualization' fostered by policies that encourage the employment of both parents and contribute to the creation of the adult earner family (Béland and Mahon, 2016, p. 63).

At a time characterized by the relative stability of the average percentage of male breadwinner couples, a decrease in dual-earner couples and an increase in female breadwinner couples (Bettio and Veraschchagina, 2014, pp. 69-70), with the simultaneous extensive cuts in social expenditures, care services included, the chances are that the burden on women who are obliged to combine paid and unpaid employment has increased. Nor is the adult-earner family supported. One should thus ask whether the concept of 'defamilialization' and the interrelated concept of 'individualization' correspond to the changes that occurred in gender norms during the years of the crisis.

Social policy scholars also need to reconsider the relationship between welfare regimes and gender regimes. For instance, the shift towards female breadwinner couples was more pronounced mainly in the Baltic countries (Estonia, Latvia and Lithuania), which are usually excluded from 'mainstream' welfare state models (Bettio and Veraschchagina, 2014, pp. 6970).

Moreover, the crisis may have contributed to a new role played by political parties and interest associations in the promotion of care, mainly through the fall in the strength of these actors, as opposed to the growing importance of transnational actors. Indeed, Fleckenstein and Seeleib-Kaiser (2011) argue that the power resource theory is not very helpful in accounting for important changes in child care and leave programmes.

\section{Conclusions}

The dramatic expansion of social policy as a field of research has been accompanied by the development of a series of theoretical assumptions that have dominated the field for decades. As discussed in the first part of this article, all 'classic' theories of welfare state development are capable of narrating (more or less convincingly) part of the story of the evolution of welfare states.

A bird's-eye view of the main theories regarding welfare state development provides the reader with the basic features of these theories. Thus: industrialism stresses the significance of socioeconomic forces for the advent of social policy programmes; power resource theory the importance of the strength of the working class, measured in terms of the proportion of the labour force that is unionized and the proportion of the electorate supporting parties of the left; historical institutionalism the role of institutions and policy legacies; national values the way that cultural beliefs lead to particular policy options; and business power the impact 
of business on social programming. Lastly, the trend of classifying welfare states drew on the aforementioned theories, but also incorporated a discussion of the role played in welfare state development by 'new' variables such as gender.

Regardless of being able to narrate part of the story of the evolution of welfare states, all theories also have their limits, as exemplified by the fact that economic factors such as industrialization cannot alone account for cross-country variation or that the historical institutionalist approach cannot easily explain processes of policy change. An indication of these limits can also be seen in the tendency of social policy scholars to combine different theories so as to better explain social phenomena.

Currently, the limits of 'classic' social policy theories are also being confronted by the challenges faced by the welfare state, as highlighted in the second part of the article. These key challenges are migration and growing ethnic diversity, neoliberal globalization and the recent crisis, as well as changing gender norms. It is argued that social policy research should focus more on these challenges and a series of interrelated issues. The aim is to understand them and what they mean for the welfare state, but also to bridge the old with the new. After drawing on a fruitful dialogue with the aforementioned challenges and the resultant issues, 'classic' theories should be retested and transformed, in line with the outcomes of new directions in social policy research; directions that, in their own turn, are in agreement with the pressing demands of our time.

This article suggests several new directions for research: For example, scholars should study more the relationship between welfare regimes and incorporation regimes for immigrants or the role that ideas play in exacerbating or mitigating the impact of migration and ethnic diversity on social policy development. In a similar vein, scholars should also pay more attention to studying the role played by transnational actors and the decrease in the percentage of dualearner families in welfare state development. A broader question for social policy scholars to explore is also whether there are types of welfare regimes or states that are more resilient to the current challenges discussed in this article.

Overall, it is unclear whether the challenges that the welfare state faces will open the way to a reassertion of the social functions of welfare states or whether they will enforce exclusion. Nonetheless, these challenges and the interrelated issues certainly test the limits of the 'classic' social policy theories and create plenty of opportunities to expand the theoretical armoury of social policy as a discipline and engage scholars in new, promising research directions.

\section{References}

Alesina, Al. and Glaeser, Ed. (2004). Fighting Poverty in the US and Europe: A World of Difference, Oxford and New York: Oxford University Press.

Amenta, Ed. (1998). Bold Relief: Institutional Politics and the Origins of Modern Americal Social Policy, Princeton, NJ: Princeton University Press.

Armingeon, K. Guthmann, K. and Weisstanner, D. (2016). 'Choosing the path of austerity: 
How parties and policy coalitions influence welfare state retrenchment in periods of fiscal consolidation', West European Politics, 39(4), pp. 628-647

Ayhan, B. and McBribe, St. (2015). 'Global crisis and social policy in peripheral Europe: comparing Ireland, Portugal and Greece', in St. McBribe, R. Mahon and G. Boychuk (eds), After '08: Social Policy and the Global Financial Crisis, Vancouver: UBC Press, pp. 237-253. Banting, K. G. and Kymlicka, W. (eds) (2006). Multiculturalism and the Welfare State: Recognition and Redistribution in Contemporary Democracies, Oxford: Oxford University Press.

Béland, D. (2010). What is Social Policy? Understanding the Welfare State, Cambridge: Polity. Béland, D. and Mahon, R. (2016). Advanced Introduction to Social Policy, Cheltenham and Northampton: Edward Elgar Publishing Limited.

Bettio, Fr. and Plantenga, J. (2004). ‘Comparing caring regimes in Europe', Feminist Economics, 10(1), pp. 85-113.

Bettio, Fr. and Veraschchagina, Al. (2014). 'Women and men in the "Great European Recession"', in M. Karamessini and J. Rubery (eds), Women and Austerity. The Economic Crisis and the Future for Gender Equality, Abington and New York: Routledge, pp. 57-81.

Castles, F. and Mitchell, D. (1993). 'Worlds of welfare and families of nations', in Fr. Castles (ed.), Families of Nations: Patterns of Public Policy in Western Democracies, Aldershot: Dartmouth, pp. 93-128.

Castles, St. and Miller, M. J. (2009). The Age of Migration: International Population Movements in the Modern World, Basingstoke: Palgrave Macmillan (4th edn).

Castles, St. and Schierup, C.-Ul. (2012). 'Migration and ethnic minorities', in Fr. Castles et al. (eds) The Oxford Handbook of the Welfare State, Oxford: Oxford University Press, pp. 278-291.

Cerny, Ph. (1997). 'Paradoxes of the competition state: dynamics of political globalization', Government and Opposition, 35(2), pp. 251-274.

Domhoff, W. (1996). State Autonomy or Class Dominance? Case Studies on Policy Making in America, New York: Aldine de Gruyter.

Esping-Andersen, G. (1985a). Politics Against Markets: The Social Democratic Road to Power, Princeton, NJ: Princeton University Press.

Esping-Andersen, G. (1985b). 'Power and distributional regimes', Politics and Society, 14(2), pp. 223-256.

Esping-Andersen, G. (1990). The Three Worlds of Welfare Capitalism, Princeton, NJ: Princeton University Press.

Esping-Andersen, G. (1999). Social Foundations of Post-Industrial Economies, Oxford and New York: Oxford University Press.

Esping-Andersen, G. (2003). 'Towards the good society, once again?', Paper presented at the 4th International Research Conference on Social Security of the International Social Security Association (ISSA, Geneva), Antwerpen, 5-7 May.

Farnsworth, K. and Irving, Z. (2015). 'A new era for social policy? Welfare states and the financial crisis', in St. McBribe, R. Mahon and G. Boychuk (eds), After '08: Social Policy and the Global Financial Crisis, Vancouver: UBC Press, pp. 59-84.

Ferrera, M. (1996). 'The "Southern Model" of welfare regimes in social Europe', Journal of European Social Policy, 6(1), pp. 17-36. 
Fleckenstein, T and Seeleib-Kaiser, M (2011). 'Business, skills and the welfare state: the political economy of employment oriented family policy in Britain and Germany', Journal of European Social Policy, 21(2), pp. 136-149.

Garrett, G. (1998). 'Global markets and national policies: Collision course or virtuous cycle?', International Organization, 52(4), pp. 787-824.

Glyn, An. (2006). Capitalism Unleashed, Finance, Globalization and Welfare, Oxford: Oxford University Press.

Gordon, C. (1991). 'New Deal, old deck: business and the origins of Social Security, 19201935', Politics and Society, 19, pp. 165-207.

Guillén, An. and Pavolini, Em. (2015). 'Welfare states under strain in Southern Europe: overview of the Special Issue', European Journal of Social Security, 17(2), pp. 147-157.

Hacker, J. S. and Pierson, P. (2002). 'Business power and social policy: employment and the formation of the American welfare state', Politics and Society, 30(2), pp. 277-325.

Hall, P. A. and Soskice, D. (eds) (2001). 'An introduction to Varieties of Capitalism', in P. A. Hall and D. Soskice (eds), Varieties of Capitalism: The Institutional Foundations of Comparative Advantage, Oxford and New York: Oxford University Press, pp. 1-68.

Heclo, H. (1974), Modern Social Politics in Britain and Sweden: From Relief to Income Maintenance, New Haven, CT: Yale University Press.

Hicks, Al. (1999). Social Democracy and Welfare Capitalism, Ithaca, NY: Cornell University Press.

Huber, Ev., Ragin, Ch. and Stephens, J. D. (1993). 'Social Democracy, Christian Democracy, constitutional structure, and the welfare state', American Journal of Sociology, 99(3), pp. 711-749.

Hübscher, E. (2016). 'The politics of fiscal consolidation revisited', Journal of Public Policy, 36(4), pp. 573-601.

Immergut, El. M. (2008). 'Historical-institutionalism in political science and the problem of change', in An. Wimmer and R. Kössler (eds), Understanding Change: Models, Methodologies, and Metaphors, Palgrave-Macmillan, pp. 237-259.

Iversen, T. (2012). 'Democracy and capitalism', in Fr. Castles et al. (eds) The Oxford Handbook of the Welfare State, Oxford: Oxford University Press, pp. 183-195.

Karamessini, M. (2015). 'Structural crisis and adjustment in Greece: social regression and the challenge to gender equality', in M. Karamessini and J. Rubery (eds), Women and Austerity. The Economic Crisis and the Future for Gender Equality, Nissos Editions, pp. 239-278 (in Greek).

Karamessini, M. and Rubery, J. (2014). 'Economic crisis and austerity: challenges to gender equality', in M. Karamessini and J. Rubery (eds), Women and Austerity. The Economic Crisis and the Future for Gender Equality, Abington and New York: Routledge, pp. 314-351.

Kersbergen, K. van and Manow, Ph. (2012). 'Religion', in Fr. Castles et al. (eds), The Oxford Handbook of the Welfare State, Oxford: Oxford University Press, pp. 265-277.

Korpi, W. (1980). 'Social policy and distributional conflict in the capitalist democracies. A preliminary comparative framework', West European Politics, 3(2), pp. 296-315.

Korpi, W. (2006). 'Power resources and employer centred approaches in explaining welfare 
states and varieties of capitalism: protagonists, consenters and antagonists', Paper presented at the ESPAnet conference, University of Bremen, 21-23 September.

Lehndorff, S. (2012). 'Introduction - The triumph of failed ideas', in S. Lehndorff (ed.), A Triumph of Failed Ideas. European Models of Capitalism in the Crisis, Brussels: ETUI.

Levine, D. (1988). Poverty and Society: The Growth of the American Welfare State in International Comparison, New Brunswick, NJ: Rutgers University Press.

Lewis, J. (1992). 'Gender and the development of welfare regimes', Journal of European Social Policy, 2(1), pp. 159-173.

Lipset, S. M. (1990). Continental Divide: The Values and Institutions of the United States and Canada, New York: Routledge.

Lister, R. (1994). '"She has other duties" - women, citizesnhip and social security', in S. Baldwin and J. Falkingham (eds), Social Security and Social Change: New Challenges to the Beveridge Model, Hempel Hempstead: Harvester Wheatsheaf, pp. 31-44.

Mares, Is. (2003). The Politics of Social Risk: Business and Welfare State Development, Cambridge and New York: Cambridge University Press.

Mishra, R. (1999). Globalization and the Welfare State, Cheltenham, UK and Northampton, MA, USA: Edward Elgar Publishing.

Myles, J. (1998). 'How to design a "liberal" welfare state: a comparison of Canada and the United States', Social Policy and Administration, 32(4), pp. 341-364.

Myles, J. and Quadagno, J. (2002). 'Political theories of the welfare state', Social Service Review, 76(1), pp. 34-57.

O' Connor, J. S. (1993). 'Gender, class and citizenship in the comparative analysis of welfare regimes: theoretical and methodological issues', British Journal of Sociology, 44(3), pp. 501-518.

O’ Connor, J. Orloff, An. and Shaver, Sh. (1999). States, Markets, Families: Gender, Liberalism and Social Policy in Australia, Canada, Great Britain and the United States, Cambridge: Cambridge University Press.

Orloff, An. Sh. (1993). 'Gender and social rights of citizenship: the comparative analysis of gender relations and welfare states', American Sociological Review, 58, pp. 303-328.

Peters, B. G., Pierre, J. and King, D.S. (2005). 'The politics of path dependency: political conflict in historical institutionalism', The Journal of Politics, 67(4), pp. 1275-1300.

Pierson, P. (1993). 'When effect becomes cause: policy feedback and political change', World Politics, 45(4), pp. 595-628.

Pierson, P. (1994). Dismantling the Welfare State? Reagan, Thatcher, and the Politics of Retrenchment, Cambridge and New York: Cambridge University Press.

Pierson, P. (1996). 'The new politics of the welfare state', World Politics, 48, pp. 143-179.

Pierson, P. (2011). 'The welfare state over the very long run', ZES Working Paper 02/2011.

Quadagno, J. (1984). 'Welfare capitalism and the Social Security Act of 1935', American Sociological Review, 45, 632-647.

Rubery, J. (2014). 'From “women and recession" to "women and austerity"', in M. Karamessini and J. Rubery (eds), Women and Austerity. The Economic Crisis and the Future for Gender Equality, Abington and New York: Routledge, pp. 17-36. 
Sainsbury, D. (1996). Gender, Equality and Welfare States, Cambridge and New York: Cambridge University Press.

Sainsbury, D. (2012). Welfare States and Immigrant Rights: The Politics of Inclusion and Exclusion, Oxford and New York: Oxford University Press.

Schierup, C.-Ul., Hansen, P. and Castles, St. (2006), Migration, Citizesship and the European Welfare State: A European Dilemma, Oxford: Oxford University Press.

Simonazzi, An. (2009). 'Care regimes and national employment models', Cambridge Journal of Economics, 33(2), pp. 211-232.

Skocpol, Th. (1985). 'Bringing the state back in: strategies of analysis in current research', in P.B. Evans, D. Rueschemeyer and Th. Skocpol (eds), Bringing the State Back In, Cambridge and New York: Cambridge University Press, pp. 3-38.

Skocpol, Th. (1992). Protecting Soldiers and Mothers: The Political Origins of Social Policy in the United States, Cambridge, MA: Belknap Press of Harvard University Press.

Steinmo, S. (2008). 'Historical institutionalism', in D. Della Porta and M. Keating (eds), Approaches and Methodologies in the Social Sciences. A Pluralist Approach, Cambridge: Cambridge University Press, pp. 118-138.

Steinmo, S., Thelen, K. and Longstreth, Fr. (eds) (1992). Structuring Politics: Historical Institutionalism in Comparative Perspective, Cambridge: Cambridge University Press.

Streeck, W. (2014). Buying Time: The Delayed Crisis of Democratic Capitalism, London: Verso. Svallfors, St. (2012), 'Public attitudes', Fr. Castles et al. (eds) The Oxford Handbook of the Welfare State, Oxford: Oxford University Press, pp. 241-251.

Swank, D. (2002). Global Capital, Political Institutions, and Policy Change, Cambridge and New York: Cambridge University Press.

Swenson, P. (1997). 'Arranged alliance: business interests in the New Deal', Politics and Society, 25 (March), pp. 66-116.

Thelen, K. (2014). Varieties of Liberalization and the New Politics of Social Solidarity, Cambridge: Cambridge University Press.

Titmuss, R. M (1974). Social Policy, London: George Allen \& Unwin.

Weaver, R. K. (2010). 'Paths and forks or chutes and ladders: negative feedbaks and policy regime change', Journal of Public Policy, 30(2), pp. 137-162.

Weir, M., Orloff, An. and Skocpol, Th. (eds) 1988. The Politics of Social Policy in the United States. Princeton, N.J.: Princeton University Press.

Wilensky, H. (1975). The Welfare State and Equality: Structural and Ideological Roots of Public Expenditures, Berkeley, CA: University of California Press.

Wilensky, H. (2002). Rich Democracies: Political Economy, Public Policy, and Performance, Berkeley, CA: University of California Press.

Wilensky, H. and Lebeaux, C.N. (1958). Industrial Society and Social Welfare, New York: Russell Sage.

Zutavern, J. and Kohli, M. (2012). 'Needs and risks in the welfare state', in Fr. Castles et al. (eds) The Oxford Handbook of the Welfare State, Oxford: Oxford University Press, pp. 169-182. 